\title{
Cerato-platanin family proteins: one function for multiple biological roles?
}

\author{
Ivan Baccelli* \\ Dipartimento di Scienze delle Produzioni Agroalimentari e dell'Ambiente, Università degli Studi di Firenze, Firenze, Italy \\ ${ }^{*}$ Correspondence: ivan.baccelli@unifi.it
}

Edited by:

Brigitte Mauch-Mani, Université de Neuchâtel, Switzerland

Reviewed by:

Vincenzo Lionetti, Sapienza "Università di Roma," Italy

Keywords: cell wall loosening, fungal growth, turgor pressure, virulence, MAMP, effectors, expansins, snodprot

\section{INTRODUCTION}

Despite the increasing number of sequenced genomes, cerato-platanin family proteins (CPPs) seem to exist only in fungi. Bacteria, oomycota, plants, and animals do not in fact possess CP homologs, whereas genes codifying for CPPs have been found, so far, in more than 50 fungal genomes (Chen et al., 2013).

Among these fungi there are plant pathogens, such as Botrytis cinerea and Magnaporthe grisea (Ascomycota), Heterobasidion irregulare and Moniliophthora perniciosa (Basidiomycota), but also biocontrol agents (e.g., Trichoderma spp.), mycorrhizal fungi, saprotrophs, and human pathogens.

Experimental data suggest that CPPs play a role during fungus-plant interactions. When $T$. virens and T. harzianum were respectively co-cultured with cotton or tomato roots, the expression of CPPs increased compared to the culture obtained in the absence of the plant (Djonović et al., 2006; Samolski et al., 2009); in B. cinerea and M. grisea, knockout mutants for CPP genes showed reduced virulence on their plant hosts (see Table 1) (Jeong et al., 2007; Frías et al., 2011).

Plants have developed the ability to recognize CPPs and to activate defense responses when in contact with them. In fact, CPPs have been reported to act as microbe/pathogen-associated molecular patterns (MAMPs/PAMPs) (for reviews, see Gaderer et al., 2014; Pazzagli et al., 2014).

The secretion of these small proteins (120-130 a.a.) seems to be universal in fungi. CPPs are often the most present in the culture filtrates, but in some studies they have been found localized in the fungal cell walls (Boddi et al., 2004; Seidl et al., 2006; Shah et al., 2009; Frías et al., 2014).

Gene knockout experiments have not yet permitted the identification of a clear biological function, and to date it is not easy to answer the question of why fungi produce CPPs. Gene expression data and studies on their biochemical properties have led to the formulation of various hypotheses that may appear different for each homolog. In summary, it is generally believed that CPPs play at least two roles in fungi: one in growth and development (generally referred to as the primary role), which should justify their presence in the cell wall, and one, more elusive, that should explain their secretion and the interaction with plants (Gaderer et al., 2014; Pazzagli et al., 2014). But what is their function?

This opinion article will attempt to answer these questions: can we hypothesize a basal function which characterizes CPPs and allows them to have multiple biological roles depending on the context (fungal cell wall or extracellular environment)? Can this function imply a role in plant colonization?

\section{CERATO-PLATANIN FAMILY PROTEINS AND EXPANSINS: MORE THAN A STRUCTURAL SIMILARITY}

CPPs are not hydrophobin-like proteins as initially hypothesized, because they have different biochemical and structural properties (Frischmann et al., 2013). On the contrary, they are similar to expansins for many aspects.
Structurally, CPPs have a single domain (named "cerato-platanin domain") which forms a double $\Psi \beta$-barrel fold similar to the domain 1 (D1) of expansins (de Oliveira et al., 2011; de O Barsottini et al., 2013). Expansins contain two domains: the N-terminal domain (D1) forms the double $\Psi \beta$-barrel fold; the C-terminal domain (D2) has an immunoglobulin-like $\beta$-sandwich fold and is similar to a family of grass-pollen allergens (Yennawar et al., 2006; Georgelis et al., 2011).

Expansins and expansin-like proteins are possessed by plants, fungi, bacteria, and other organisms (Nikolaidis et al., 2014). In plants, expansins mediate the turgor-driven extension of plant cell walls, and they play multiple roles in plant physiology and development, including growth, fruit softening, organ abscission, and pollen tube penetration of the stigma (Sampedro and Cosgrove, 2005). In microbes, their role is still elusive (Georgelis et al., 2014).

To date, no enzymatic activity has been found for expansins, and their molecular mechanism of action has not yet welldefined. The idea is that they break noncovalent interactions between cell wall components, allowing polymer slippage (creep), and cell wall loosening (Yennawar et al., 2006).

Since expansins can weaken cellulosic substrates, their possible use in biofuel production as enhancers of enzymatic hydrolysis has received great interest (Arantes and Saddler, 2010). Like expansins, CPPs did not show any enzymatic activity but were able to weaken cellulosic materials (de O Barsottini et al., 2013; Baccelli et al., 2014). 
Table 1 | Summary table of the mutants obtained up to date for genes encoding cerato-platanin family proteins (CPPs).

\begin{tabular}{|c|c|c|c|}
\hline $\begin{array}{l}\text { Fungi mutated for } C P P \\
\text { genes }\end{array}$ & Phenotypic analysis & References & $\begin{array}{l}\text { Expansin-like } \\
\text { genes in the } \\
\text { genome }\end{array}$ \\
\hline Magnaporthe grisea & $\begin{array}{l}\text { msp1 mutants were phenotypically indistinguishable from wild type and } \\
\text { elaborated apparently normal appressoria. However, the deletion } \\
\text { mutants were greatly reduced in virulence on rice and barley primarily } \\
\text { due to impaired growth in planta }\end{array}$ & Jeong et al., 2007 & Yes \\
\hline Botrytis cinerea & $\begin{array}{l}\text { bcsp/1 mutant strains showed reduced virulence in a variety of hosts, } \\
\text { such as tomato and tobacco plants, and some fruits. Growth rates on } \\
\text { solid media, conidia production, and wettability of the fungal colonies } \\
\text { were similar to the wild type }\end{array}$ & Frías et al., 2011 & Yes \\
\hline Leptosphaeria maculans & sp1 was not crucial for pathogenicity on Brassica napus cotyledons & Wilson et al., 2002 & Yes \\
\hline
\end{tabular}

There are other interesting similarities between CPPs and expansin-like proteins that are worth summarizing: (1) CPPs, as well as expansins, have been found localized in the cell walls (Sampedro and Cosgrove, 2005; Bouzarelou et al., 2008; Gaderer et al., 2014); (2) gene expression data link both CPPs and expansins with growth and developmental processes (including, for CPPs, the formation of spores and conidia) (Cosgrove et al., 2002; Gaderer et al., 2014); (3) CPPs and fungal expansins can bind chitin (Chen et al., 2010; Baccelli et al., 2014; Gaderer et al., 2014); (4) the optimum of activity of these proteins usually occurs at an acid $\mathrm{pH}$ (Sampedro and Cosgrove, 2005; Chen et al., 2010; Baccelli et al., 2014); (5) gene knockout experiments have often led to phenotypes that are identical to wild types (for CPPs, see Table 1) (Cosgrove et al., 2002; Bouzarelou et al., 2008).

Conversely, CPPs have a main difference compared to expansins: they do not bind to cellulose, a property that seems to be universal in plant and microbial expansins (Yennawar et al., 2006; Georgelis et al., 2011; Gaderer et al., 2014).
In view of the similarities between CPPs and expansins, it seems possible to suppose that CPPs, when localized in the fungal cell wall, can act by disrupting noncovalent interactions between fungal cell wall components: for example, between $\beta$-glucan or chitin chains. This function could explain their localization and gene regulation. In fact, they could act in hyphal elongation, in the formation of spores and fruiting bodies, spore germination, and in all those processes requiring remodeling and enlargement of the fungal cell wall. It is worth reporting that the ceratoplatanin $\mathrm{MpCP} 2$ was able to facilitate the germination of basidiospores in M. perniciosa (de O Barsottini et al., 2013). The idea is that this ability to act on noncovalent bonds is due to the fold that CPPs and expansins both have. Moreover, CPPs and expansins have a conserved aspartate within the shared domain (Asp-77 and Asp-82, respectively), which is crucial in expansins for the wall extension activity (Georgelis et al., 2011).

Interestingly, in a recent study concerning the elongation growth of the stipe of Flammulina velutipes, it has been found that a protein from the snail Helix aspersa was able to induce stipe wall extension without hydrolytic activity (Fang et al., 2014). Although this $21-\mathrm{kDa}$ protein was not sequenced, this paper has reported for the first time the ability of an expansinlike protein to extend a cellulose-free wall. Interestingly, the cell wall extension was measured with an extensometer in a test analogous to that used for plant expansins. In conclusion, the hypothesis is that CPPs can act on non-covalent interactions both in cellulose- and chitin-containing walls.

If CPPs have this important function in the fungal cell wall, how can we explain that gene knockout strains did not show any phenotype related to hyphal growth or development?

As shown in Table 1, all mutated fungi possess both CPPs and expansin-like proteins in their genomes. In Trichoderma these proteins are called swollenins (Brotman et al., 2008). In other fungi, they may be called loosenins (QuirozCastañeda et al., 2011). Multiple knockout strains for CPP and expansin-like genes have never been obtained, we can therefore suppose that it is necessary to produce these multiple mutants to avoid compensation effects in fungi. 


\section{ROLE IN PLANT COLONIZATION: CERATO-PLATANIN PROTEINS MAY FACILITATE THE MECHANICAL PENETRATION OF FUNGI}

Not all CPPs are localized in the fungal cell wall (Jeong et al., 2007), whereas all CPPs are abundantly secreted outside the hyphae during growth. When knockout mutants were obtained, they never revealed differences in morphological traits compared to wild types; however, some studies have reported a reduced virulence of the mutants when tested on host plants (Table 1). This first of all implies that CPPs must have a role in the interaction with plants, as already hypothesized (Pazzagli et al., 2014); but how can they promote the interaction? Above all, can their function be useful to non-pathogenic fungi like Trichoderma?

Recently, it has been reported that MpCP5, a CPP from M. perniciosa, when pre-incubated with $\mathrm{N}$-acetylglucosamine oligomers bound to them and prevented the defense responses of tobacco seedlings (de O Barsottini et al., 2013). This could actually be a role for CPPs during the interaction with plants, i.e., as scavengers of chitin fragments produced by plant chitinases, but we do not know whether during the invasion process this property can be effective, because a direct competition assay between the scavenger and the plant receptor should be performed.

Pathogenic fungi invade their hosts both through the secretion of extracellular lytic enzymes and by exerting a physical force on the tissues (Bellincampi et al., 2014). The force is provided by the enormous turgor pressure that fungi are able to generate. M. grisea generates the turgor pressure within the appressoria by increasing the intracellular glycerol, and the pressure is applied as a physical force able to break the leaf cuticle (Bastmeyer et al., 2002; Serrano et al., 2014).

Recently, three CPPs from different fungi (CP from Ceratocystis platani, Pop1 from C. populicola and MpCP2 from M. perniciosa) have been reported to weaken filter paper without any hydrolytic activity (de O Barsottini et al., 2013; Baccelli et al., 2014). Cellulose fibers were loosened and dispersed after incubation with the protein under shaking, which actually is an external force applied to the incubation mixture. As CPPs were not tested with an extensometer, it is not possible to compare their activity with that of expansins. For example, the incubation of paper strips with the bacterial expansin EXLX1 reduced the breakage force by $20 \%$ (Georgelis et al., 2011). Therefore, this experiment and some tests on plant cell walls should be performed in future.

CPPs, through their demonstrated non-enzymatic activity on cellulose (or other plant cell wall components that should be tested), could reduce the force needed to break the plant cell walls and thus facilitate the hyphae during the mechanical penetration.

Trichoderma is able to penetrate the root tissues and colonize several epidermal layers (Brotman et al., 2008). The function here delineated would thus be useful to non-pathogenic fungi like Trichoderma, and also to mycorrhizal fungi during the establishment of the contact surface (Balestrini and Bonfante, 2014).

We cannot exclude that also fungal expansins, when secreted, play a similar role. However, in that case we can assume that CPPs are more functional: this could indeed explain why some deletion mutants would not be blurred by the presence of expansin-like proteins in their genomes. It is plausible that CPPs, because of their inability to bind cellulose, are more functional than expansins. This property would allow fungi to have proteins always active around the hyphae, and to reduce their dispersal during the penetration of the plant cell walls. Moreover, CPPs could be kept near the fungus thanks to their chitin-binding ability.

The invading strategy and the balance between the secretion of lytic enzymes and the use of mechanical pressure could, in any case, influence the importance of CPPs in each fungus-plant interaction.

\section{CONCLUDING REMARKS}

CPPs are well-known to act as elicitors on plants and seem to possess all the requirements to be classified as MAMPs, because they are widespread in fungi, have a conserved structure, are present both in pathogenic and non-pathogenic fungi, and are abundantly secreted. But what is their function in fungi? On the basis of recent results, this Opinion Article has tried to suggest the answer.
The idea is that CPPs can act in an expansin-like manner on non-covalent interactions and cause the loosening of fungal and plant cell walls. This basal function could explain why CPPs have multiple biological roles in fungal life. At the same time, CPPs and expansin-like proteins might have similar functions in fungi, and a few gene knockout experiments could have been blurred by expansins. In the host colonization, CPPs would act as facilitators of the mechanical penetration, and their ability to act on cellulose without binding to it would make them very functional.

\section{ACKNOWLEDGMENTS}

The author was supported by a grant from Ente Cassa di Risparmio di Firenze (No. 2013/0444).

\section{REFERENCES}

Arantes, V., and Saddler, J. N. (2010). Access to cellulose limits the efficiencyof enzymatic hydrolysis: the role of amorphogenesis. Biotechnol. Biofuels 3:4. doi: 10.1186/1754-6834-3-4

Baccelli, I., Luti, S., Bernardi, R., Scala, A., and Pazzagli, L. (2014). Cerato-platanin shows expansin-like activity on cellulosic materials. Appl. Microbiol. Biotechnol. 98, 175-184. doi: 10.1007/s00253-013-4822-0

Balestrini, R., and Bonfante, P. (2014). Cell wall remodeling in mycorrhizal symbiosis: a way towards biotrophism. Front. Plant Sci. 5:237. doi: 10.3389/fpls.2014.00237

Bastmeyer, M., Deising, H. B., and Bechinger, C. (2002). Force exertion in fungal infection. Annu. Rev. Biophys. Biomol. Struct. 31, 321-341. doi: 10.1146/annurev.biophys.31.091701.170951

Bellincampi, D., Cervone, F., and Lionetti, V. (2014). Plant cell wall dynamics and wall-related susceptibility in plant-pathogen interactions. Front. Plant Sci. 5:228. doi: 10.3389/fpls.2014.00228

Boddi, S., Comparini, C., Calamassi, R., Pazzagli, L., Cappugi, G., and Scala, A. (2004). Cerato-platanin protein is located in the cell walls of ascospores, conidia and hyphae of Ceratocystis fimbriata $\mathrm{f}$. $\mathrm{sp}$. platani. FEMS Microbiol. Lett. 233, 341-346. doi: 10.1111/j.1574-6968.2004.tb09501.x

Bouzarelou, D., Billini, M., Roumelioti, K., and Sophianopoulou, V. (2008). EglD, a putative endoglucanase, with an expansin like domain is localized in the conidial cell wall of Aspergillus nidulans. Fungal Genet. Biol. 45, 839-850. doi: 10.1016/j.fgb.2008.03.001

Brotman, Y., Briff, E., Viterbo, A., and Chet, I. (2008). Role of swollenin, an expansin-like protein from Trichoderma, in plant root colonization. Plant Physiol. 147, 779-789. doi: 10.1104/pp.108.116293

Chen, H., Kovalchuk, A., Keriö, S., and Asiegbu, F. O. (2013). Distribution and bioinformatic analysis of the cerato-platanin protein family in Dikarya. Mycologia 105, 1479-1488. doi: 10.3852/13-115

Chen, X. A., Ishida, N., Todaka, N., Nakamura, R., Maruyama, J., Takahashi, H., et al. (2010) 
Promotion of efficient saccharification of crystalline cellulose by Aspergillus fumigatus Swol. Appl. Environ. Microbiol. 76, 2556-2561. doi: 10.1128/AEM.02499-09

Cosgrove, D. J., Li, L. C., Cho, H. T., HoffmannBenning, S., Moore, R. C., and Blecker, D. (2002). The growing world of expansins. Plant Cell Physiol. 43, 1436-1444. doi: 10.1093/pcp/pcf180

de O Barsottini, M. R., de Oliveira, J. F., Adamoski, D., Teixeira, P. J., do Prado, P. F., Tiezzi, H. O., et al. (2013). Functional diversification of cerato-platanins in Moniliophthora perniciosa as seen by differential expression and protein function specialization. Mol. Plant Microbe Interact. 26, 1281-1293. doi: 10.1094/MPMI-05-130148-R

de Oliveira, A. L., Gallo, M., Pazzagli, L., Benedetti, C. E., Cappugi, G., Scala, A., et al. (2011). The structure of the elicitor Cerato-platanin (CP), the first member of the CP fungal protein family, reveals a double $\psi \beta$-barrel fold and carbohydrate binding. J. Biol. Chem. 286, 17560-17568. doi: 10.1074/jbc.M111.223644

Djonović, S., Pozo, M. J., Dangott, L. J., Howell, C. R., and Kenerley, C. M. (2006). Sm1, a proteinaceous elicitor secreted by the biocontrol fungus Trichoderma virens induces plant defense responses and systemic resistance. Mol. Plant Microbe Interact. 19, 838-853. doi: 10.1094/MPMI-19-0838

Djonović, S., Vargas, W. A., Kolomiets, M. V., Horndeski, M., Wiest, A., and Kenerley, C. M. (2007). A proteinaceous elicitor Sml from the beneficial fungus Trichoderma virens is required for induced systemic resistance in maize. Plant Physiol. 145, 875-889. doi: 10.1104/pp.107.103689

Fang, H., Zhang, W., Niu, X., Liu, Z., Lu, C., Wei, H., et al. (2014). Stipe wall extension of Flammulina velutipes could be induced by an expansin-like protein from Helix aspersa. Fungal Biol. 118, 1-11. doi: 10.1016/j.funbio.2013.10.003

Frías, M., Brito, N., González, M., and González, C. (2014). The phytotoxic activity of the ceratoplatanin BcSpll resides in a two-peptide motif on the protein surface. Mol. Plant Pathol. 15, 342-351. doi: 10.1111/mpp. 12097

Frías, M., González, C., and Brito, N. (2011). BcSpll, a cerato-platanin family protein, contributes to Botrytis cinerea virulence and elicits the hypersensitive response in the host. New Phytol. 192, 483-495. doi: 10.1111/j.1469-8137.2011.03802.x
Frischmann, A., Neudl, S., Gaderer, R., Bonazza, K., Zach, S., Gruber, S., et al. (2013). Self-assembly at air/water interfaces and carbohydrate binding properties of the small secreted protein EPL1 from the fungus Trichoderma atroviride. J. Biol. Chem. 288, 4278-4287. doi: 10.1074/jbc.M112.427633

Gaderer, R., Bonazza, K., and Seidl-Seiboth, V. (2014) Cerato-platanins: a fungal protein family with intriguing properties and application potential. Appl. Microbiol. Biotechnol. 98, 4795-4803. doi: 10.1007/s00253-014-5690-y

Georgelis, N., Nikolaidis, N., and Cosgrove, D. J. (2014). Biochemical analysis of expansin-like proteins from microbes. Carbohydr. Polym. 100, 17-23. doi: 10.1016/j.carbpol.2013.04.094

Georgelis, N., Tabuchi, A., Nikolaidis, N., and Cosgrove, D. J. (2011). Structure-function analysis of the bacterial expansin EXLX1. J. Biol. Chem. 286, 16814-16823. doi: 10.1074/jbc.M111. 225037

Jeong, J. S., Mitchell, T. K., and Dean, R. A. (2007). The Magnaporthe grisea snodprotl homolog, MSP1, is required for virulence. FEMS Microbiol. Lett. 273, 157-165. doi: 10.1111/j.1574-6968.2007.00796.x

Nikolaidis, N., Doran, N., and Cosgrove, D. J. (2014). Plant expansins in bacteria and fungi: evolution by horizontal gene transfer and independent domain fusion. Mol. Biol. Evol. 31, 376-386. doi: $10.1093 / \mathrm{molbev} / \mathrm{mst} 206$

Pazzagli, L., Seidl-Seiboth, V., Barsottini, M., Vargas, W. A., Scala, A., and Mukherjee, P. K. (2014). Cerato-platanins: elicitors and effectors. Plant Sci. 228, 79-87. doi: 10.1016/j.plantsci.2014. 02.009

Quiroz-Castañeda, R. E., Martínez-Anaya, C., Cuervo-Soto, L. I., Segovia, L., and FolchMallol, J. L. (2011). Loosenin, a novel protein with cellulose-disrupting activity from Bjerkandera adusta. Microb. Cell Fact. 10:8. doi: 10.1186/1475-2859-10-8

Samolski, I., de Luis, A., Vizcaíno, J. A., Monte, E., and Suárez, M. B. (2009). Gene expression analysis of the biocontrol fungus Trichoderma harzianum in the presence of tomato plants, chitin, or glucose using a high-density oligonucleotide microarray. BMC Microbiol. 9:217. doi: 10.1186/14712180-9-217

Sampedro, J., and Cosgrove, D. J. (2005). The expansin superfamily. Genome Biol. 6:242. doi: 10.1186/gb-2005-6-12-242
Serrano, M., Coluccia, F., Torres, M., L'Haridon, F., and Métraux, J. P. (2014). The cuticle and plant defense to pathogens. Front. Plant Sci. 5:274. doi: 10.3389/fpls.2014.00274

Shah, P., Atwood, J. A., Orlando, R., El Mubarek, H., Podila, G. K., and Davis, M. R. (2009). Comparative proteomic analysis of Botrytis cinerea secretome. J. Proteome Res. 8, 1123-1130. doi: $10.1021 /$ pr8003002

Seidl, V., Marchetti, M., Schandl, R., Allmaier, G., and Kubicek, C. P. (2006). Epll, the major secreted protein of Hypocrea atroviridis on glucose, is a member of a strongly conserved protein family comprising plant defense response elicitors. FEBS J. 273, 4346-4359. doi: 10.1111/j.17424658.2006.05435. $\mathrm{x}$

Wilson, L. M., Idnurm, A., and Howlett, B. J. (2002). Characterization of a gene (spl) encoding a secreted protein from Leptosphaeria maculans, the blackleg pathogen of Brassica napus. Mol. Plant Pathol. 3, 487-493. doi: 10.1046/j.13643703.2002.00144.x

Yennawar, N. H., Li, L. C., Dudzinski, D. M., Tabuchi, A., and Cosgrove, D. J. (2006). Crystal structure and activities of EXPB1 (Zea m 1), a beta-expansin and group-1 pollen allergen from maize. Proc. Natl. Acad. Sci. U.S.A. 103, 14664-14671. doi: 10.1073/pnas.0605979103

Conflict of Interest Statement: The author declares that the research was conducted in the absence of any commercial or financial relationships that could be construed as a potential conflict of interest.

Received: 20 November 2014; paper pending published: 04 December 2014; accepted: 12 December 2014; published online: 06 January 2015.

Citation: Baccelli I (2015) Cerato-platanin family proteins: one function for multiple biological roles? Front. Plant Sci. 5:769. doi: 10.3389/fpls.2014.00769

This article was submitted to Plant-Microbe Interaction, a section of the journal Frontiers in Plant Science.

Copyright () 2015 Baccelli. This is an open-access article distributed under the terms of the Creative Commons Attribution License (CC BY). The use, distribution or reproduction in other forums is permitted, provided the original author(s) or licensor are credited and that the original publication in this journal is cited, in accordance with accepted academic practice. No use, distribution or reproduction is permitted which does not comply with these terms. 